\title{
Localization of antigenic domains on the major subunits of Bordetella pertussis serotype 2 and 3 fimbriae
}

\author{
A. M. Pearce, R. N. Seabrook, L. I. Irons, L. A. E. Ashworth, T. Atkinson \\ and A. Robinson
}

Author for correspondence: R. N. Seabrook. Tel: +44980 612100. Fax: +44980611096.

Divisions of Biologics, Biotechnology and Pathology, PHLS, Centre for Applied Microbiology and Research, Porton Down, Salisbury SP4 0JG, UK

\begin{abstract}
Antibody-binding domains on the major subunits of Bordetella pertussis serotype 2 (Fim2) and 3 fimbriae (Fim3) have been identified using synthetic peptides which were screened for recognition by anti-protein monoclonal antibodies (mAbs). The presence of non-contiguous fimbrial epitopes was demonstrated by both anti-Fim2 and anti-Fim 3 mAbs, several of which recognized at least two peptides that were discontinuous in the amino acid sequence of the corresponding subunits. The specificity of one mAb, 51/24, directed against Fim2, was investigated by replacement-set analysis of a 10-residue peptide, and revealed that antibody binding to the peptide was dependent on the sequence $\mathrm{N}^{94} \mathrm{PQ}^{96}$ which is non-conserved in Fim3. Furthermore, proline at residue 95 was found to be essential for mAb 51/24 binding. The specific anti-Fim 3 mAb, AG3A, was found to recognize the 10-residue carboxy-terminal peptide from both Fim 3 and, unexpectedly, from Fim2. This result suggests that mAb AG3A serospecificity at the protein level is determined by a conformational constraint which prevents mAb AG3A binding to the Fim2 C-terminal domain. Several free peptides containing amino acid residues which comprise part of the Fim 2 and Fim 3 epitopic domains were prepared as immunogens. One of these peptides was immunogenic in the mouse, indicating the location of a T-helper cell epitope within the peptide sequence, and induced a strong anti-peptide antibody response. The other peptides each required immunization as a conjugate with a carrier protein for anti-peptide antibody stimulation. All four anti-peptide antibody preparations only weakly recognized fimbriae-coated ELISA plates. The results of this investigation demonstrate that although short linear peptides can mimic sub-domains of non-contiguous fimbrial epitopes, they are, however, poor candidate antigens for stimulating an anti-fimbrial antibody response.
\end{abstract}

Keywords: Bordetella pertussis, fimbriae, antigenic domain

\section{INTRODUCTION}

Bordetella pertussis, the aetiological agent of whooping cough, can express two separate fimbrial proteins (Fim2 and Fim3) which are important for the colonization of the host's respiratory tract (Robinson et al., 1991). Fim2 and

\footnotetext{
Abbreviations: $C B S A$, cationized bovine serum albumin; $K L H$, keyhole limpet haemocyanin; mAb, monoclonal antibody; MBS, $m$-maleimido$\mathrm{N}$-hydroxysuccinimide ester; SMCC, sulpho-succinimidyl trans-4-( $\mathrm{N}$ maleimidomethyl)-cyclohexane-1-carboxylate; TFE, trifluoroethanol.
}

Fim 3 are each assembled into helical structures (Steven $e t$ al., 1986) from multiple copies of their distinct major subunits, which possess molecular masses of $22.5 \mathrm{kDa}$ and $22.0 \mathrm{kDa}$, respectively (Irons et al., 1985). Recent evidence indicates that the fimbriae are also comprised of accessory subunits which may serve as scaffolding or adhesion proteins (Willems et al., 1992). The DNA-derived amino acid sequences of the major subunits of Fim2 (Livey et al., 1987) and Fim3 (Mooi et al., 1990) display $67 \%$ overall amino acid homology, and are particularly conserved at the amino and carboxy termini. Despite the high amino acid sequence identity of these subunits, the fimbriae are 
serospecific, with only weak cross-reactivity being demonstrated by antibodies which have been raised to either the purified proteins (Ashworth et al., 1985; Robinson, et al., 1989) or induced during the disease process (Preston, 1985; Robinson et al., 19\{9). Both fimbriae are regarded as important compcnents for vaccines designed to prevent bacterial culonization (Robinson et al., 1989). An understanding of the antigenic structure and the localization of the serospecific fimbrial epitopes could lead to the development of simpler acellular vaccines designed to protect infants from whooping cough.

In this study, sets of multiple overlapping peptides which consecutively spanned the amino acid sequences of the two major subunits were screened with various monoclonal antibodies (mAbs) in order to identify subunit epitopes. The peptides were synthesized and used for antibody screening on polyethylene pins as previously described for the epitope mapping technique (Geysen et al., 1984). This procedure has successfully been used to identify many protein epitopes, including those of bacterial pili (Cassels et al., 1992). Several of the peptides which were recognized by the mAbs were re-synthesized as 'free' peptides and prepared as immunogens to assess their potential for inducing a fimbrial-recognizing antibody response.

\section{METHODS}

Materials. The following were purchased from Sigma: antimouse immunoglobulin enzyme conjugates, bovine serum albumin (BSA), glutaraldehyde, keyhole limpet haemocyanin (KLH), $m$-maleimido- $N$-hydroxysuccinimide ester (MBS), trifluoroethanol (TFE) and Tween 20. Reagents for pin-peptide synthesis were obtained from Cambridge Research Biochemicals (ICI). The co-purified preparation of Fim $2+$ Fim 3 was derived from $B$. pertussis strain Wellcome 28 by the method of Robinson et al. (1989).

Epitope mapping. Consecutive overlapping peptides, synthesized on polyethylene pins and corresponding, respectively, to the Fim 2 and Fim 3 major subunit amino acid sequences (Livey et al., 1987; Mooi et al., 1990), were prepared using the protocol already described (Tallet et al., 1993). Both 10- and 8-residue peptides, overlapping by 5 and 6 residues, respectively, were synthesized for each subunit amino acid sequence. The 10amino-acid-residue peptide 19 from Fim2 was also prepared as a series of substitution peptides in a replacement-set synthesis (Getzoff et al., 1987). This involved synthesizing $(10 \times 19) 10$ residue analogue peptides of the parent peptide, in which a different residue of the parent peptide was iteratively replaced by the 19 alternative amino acids. Antibody preparations were screened, either as a dilution of the polyclonal sera or as purified monoclonal immunoglobulin $\left(20-50 \mu \mathrm{g} \mathrm{m}^{-1}\right)$, for binding to the pin-peptides as previously described (Tallet $e t$ al., 1993), but with species-specific peroxidase antibody conjugates used as the second antibody.

Synthesis of 'free' peptides and peptide conjugation to carrier proteins. Free peptides 1 Fim 2 and 2 Fim2 were each manually synthesized by t-Boc chemistry (Kent, 1988) on $N^{x}$ Boc-S-4-methylbenzyl-L-cysteine phenylacetamidomethyl resins (Bachem), and free peptides 1Fim 3 and 2Fim 3 were prepared by Applied Biosystems FastMoc chemistry (Kent, 1988) on an automated synthesizer using 4-[2',4'-dimethoxyphenyl- $N$-(9fluorenyl methoxy carbonyl)-amino methyl] phenoxy resins (Novabiochem). Following peptide-resin deprotection and cleavage, the peptides were purified by gel filtration and reversephase HPLC on a $V_{y d a c} C_{8}$ column. Peptide composition was confirmed by fast-atom-bombardment mass spectrometry. The purified peptides were conjugated to carrier proteins as follows: (1) cross-linking to KLH via the peptidyl cysteine was achieved with MBS using the method of Green et al. (1982); (2) glutaraldehyde was used to couple peptides to BSA as previously described (Seabrook et al., 1990); and (3) conjugation to cationized BSA (cBSA) (Supercarrier, Pierce Chemical) was obtained through the peptidyl cysteine with sulphosuccinimidyl trans-4-( $N$-maleimidomethyl)-cyclohexane-1-carboxylate (SMCC) according to the manufacturer's instructions (Pierce Chemical).

Immunization and antibodies. Murine polyclonal antibodies were induced following intraperitoneal immunization of Porton $\mathrm{NIH}$ mice (H-2 ${ }^{\mathrm{q}}$ haplotype) with $10 \mu \mathrm{g}$ of peptide or peptide carrier conjugate. Each immunogen was pre-adsorbed onto $25 \%(\mathrm{v} / \mathrm{v})$ alhydrogel (Superfos) as adjuvant. Mice were boosted at 3 weeks and sera collected at 6 weeks after primary immunization. The anti-Fim2 mAbs, 51/21 ( $\operatorname{IgG}), 51 / 24(\operatorname{IgG})$, AG2A $(\operatorname{IgM})$ and $A G 2 B(\operatorname{IgM})$, and the $\operatorname{IgM}$ anti-Fim $3 \mathrm{mAbs}$ AG3A, AG3B and AG3C were derived previously (Ashworth $e t$ al., 1985). Purified immunoglobulin was obtained either by gel filtration with Superose 6 (Pharmacia) or by affinity chromatography with protein A Sepharose (Pharmacia).

ELISA. Plates were coated with either synthetic peptides or native protein as described before (Seabrook et al., 1990). Whole-cell ELISA plates were prepared by diluting a formalininactivated culture of $B$. pertussis (strain Wellcome 28; Fim2 ${ }^{+}$ Fim $3^{+}$), grown on charcoal agar containing $10 \%(\mathrm{v} / \mathrm{v})$ defibrinated horse blood, to an $\mathrm{OD}_{670}$ of 0.9 and $100 \mu \mathrm{l}$ aliquoted to the wells of the ELISA piate. After overnight evaporation at $37^{\circ} \mathrm{C}$, these plates were washed with phosphate-buffered saline, $\mathrm{pH} 7 \cdot 2$, containing $0 \cdot 1 \%(\mathrm{v} / \mathrm{v})$ Tween 20 . Primary antibodies were employed in each ELISA as a serial dilution and the colour and endpoint titre, calculated as the antibody dilution which would yield an $A_{450}$ of $1 \cdot 0$, were obtained as before (Seabrook et al., 1990).

Circular dichroism. Far-UV circular dichroism spectra (250$190 \mathrm{~nm}$ ) of peptide 1 Fim 2 in TFE $/ \mathrm{H}_{2} \mathrm{O}$ mixtures were measured with a Jasco-J 600 spectropolarimeter at a peptide concentration of $17 \mu \mathrm{M}$ in a $0.05 \mathrm{~cm}$ pathlength cell. Four spectra, measured for each solution at a scan speed of $10 \mathrm{~nm} \mathrm{~min}{ }^{-1}$ and time constant of $4 \mathrm{~s}$, were computer-averaged. Similarly averaged blank spectra were subtracted, and corrected spectra converted to mean residue ellipticities $[\theta]$ using a mean residue weight of $110 \cdot 5$ for the peptide.

\section{RESULTS}

\section{Fim2 epitope mapping}

Four purified mAbs, AG2A, AG2B, 51/24 and 51/21, which are effectively serospecific for the Fim2 protein, were initially screened for recognition of 10-amino-acidresidue peptides, overlapping by five amino acids, which consecutively spanned the complete amino acid sequence of the mature Fim2 subunit. The only antibody able to demonstrate unequivocal binding to a synthetic peptide was 51/24 (Fig. 1a). This antibody recognized peptide 19 $\left(\mathrm{Y}^{91}\right.$ ATNPQTQLS ${ }^{100}$ ) and did not bind the correspond- 

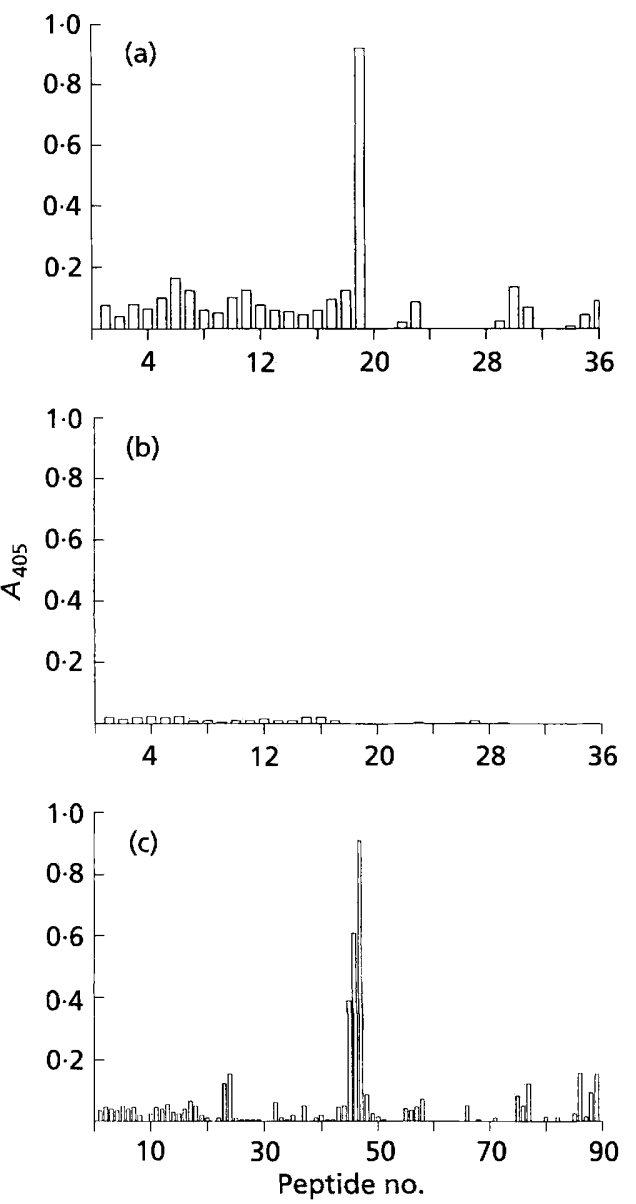

Fig. 1. Epitope mapping with mAb 51/24 of (a) consecutive 10residue peptides of Fim 2 overlapping by five amino acids, (b) as (a) with Fim3 peptides and (c) consecutive 8-residue Fim2 peptides overlapping by six amino acids.

ing Fim3 peptide, peptide 18 ( $\left.\mathrm{Y}^{90} \mathrm{NASGNGQLS}{ }^{99}\right)$, which shows $40 \%$ sequence homology (Fig. 1b). When this $\mathrm{mAb}$ was screened with Fim 2 peptides of eight amino acids overlapping by six residues (Fig. 1c), antibody binding was found to be directed against the same protein domain as that delineated by the 10 -residue peptides, but had been dispersed over three overlapping peptides. \left. These were peptides $45{\left(\mathrm{M}^{89} \text { VYATNPQ }\right.}^{96}\right), 46$ $\left(\mathrm{Y}^{91} \mathrm{ATNPQTQ}^{98}\right)$ and 47 (T $\left.^{93} \mathrm{NPQTQLS}^{100}\right)$, which share the consensus sequence $\mathrm{T}^{93} \mathrm{NPQ}^{96}$. Other anti-Fim2 $\mathrm{mAbs}$ reacted less strongly with these peptides.

\section{Replacement-set analysis of the mAb 51/24 antigenic peptide 19}

To identify the amino acids of the 10 -residue peptide, $\mathrm{Y}^{91} \mathrm{~A} T N P Q T Q L S^{100}$, which contribute to binding the $\mathrm{mAb} 51 / 24$ paratope, each residue was iteratively substituted with the 19 alternative naturally occurring Lamino acids in a replacement-set (Getzoff et al., 1987). When the resultant substitution peptides were screened
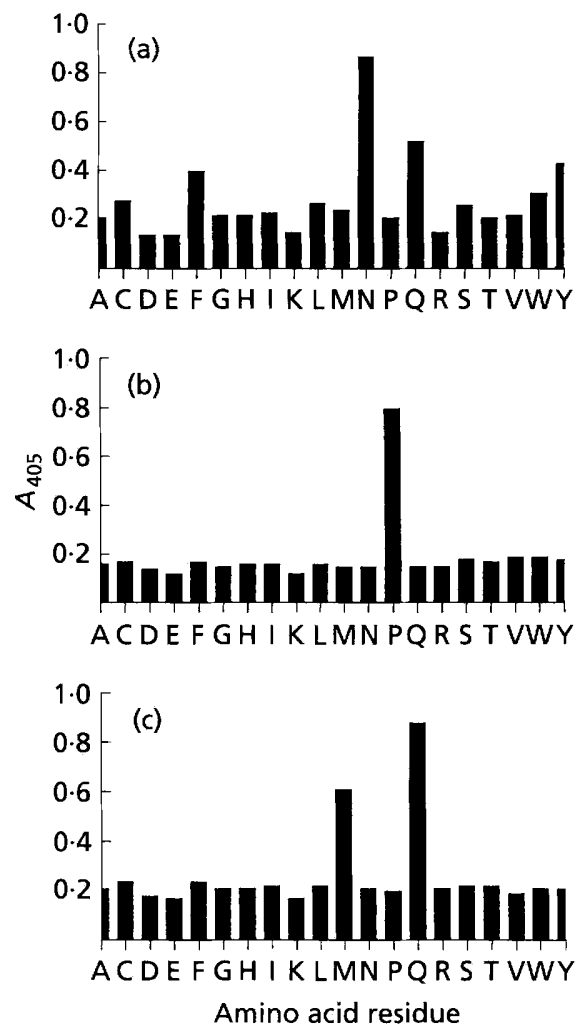

Fig. 2. Replacement-set analysis of (a) $N^{94}$ (b) $P^{95}$ and (c) $Q^{96}$ from Fim2 peptide 19, $\mathrm{Y}^{91}$ ATNPQTQLS ${ }^{100}$. Peptides were screened with mAb 51/24.

for $\mathrm{mAb} 51 / 24$ binding (Fig. 2), it was found that the residues $\mathrm{Y}^{91} \mathrm{AT}^{93}$ and $\mathrm{T}^{97} \mathrm{QL} \mathrm{S}^{100}$ could be substituted without significant detriment to antibody binding, but residues comprising the sequence $\mathrm{N}^{94} \mathrm{PQ}^{96}$, which are part of the previously deduced consensus sequence, were essential for paratope recognition. For example, $\mathrm{N}^{94}$ could only be substituted with the conserved amino acid glutamine and by the hydrophobic amino acids tyrosine and phenylalanine (Fig. 2a). There was an absolute requirement for $\mathrm{P}$ at residue 95 , and replacement of this residue by any of the other amino acids used in the replacement-set resulted in a loss of $\mathrm{mAb}$ recognition (Fig. 2b). Interestingly, $\mathrm{Q}^{96}$ could not be replaced by an asparagine residue, but substitution with methionine was possible without complete loss of $\mathrm{mAb}$ recognition (Fig. 2c).

\section{Fim3 epitope mapping}

Three Fim 3 serospecific $m A$ bs, AG3A, AG3B and AG3C, were screened for their ability to recognize 10 -aminoacid-residue peptides which consecutively spanned the complete amino acid sequence of the mature Fim 3 subunit (Mooi et al., 1990). Only two of the purified mAbs, AG3A and AG3B, demonstrated significant binding to any of the synthetic peptides, which were principally those of the central and C-terminal domain (Fig. 3a and 


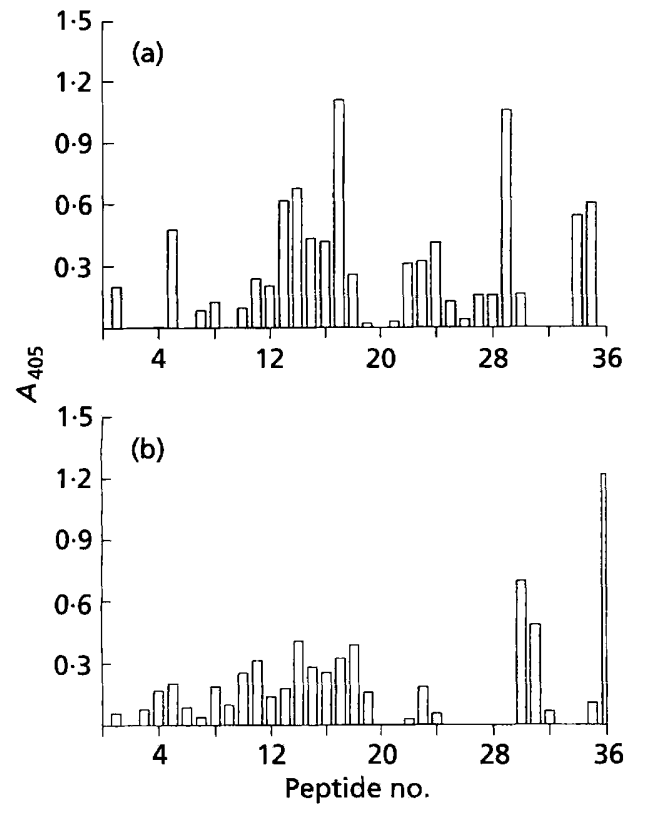

Fig. 3. Epitope mapping with mAb AG3A of 10-residue peptides overlapping by five amino acids which were derived from (a) Fim3 or (b) Fim2.

Fig. 4a). For AG3A, recognition of peptides 17 $\left(\mathrm{G}^{81}\right.$ DLIAYKTQTY ${ }^{\mathbf{9 0}}$ ) and 29 ( $\left.\mathrm{T}^{\mathbf{1 4 1}} \mathrm{NGSKSYTLR}^{150}\right)$ was most marked. There was also appreciable crossreaction of $A G 3 A$ with the $C$-terminal Fim2 peptide 36 ( $\mathrm{T}^{198}$ YVGFSVVYP $^{207}$ ) (Fig. 3b). Fim3 peptide 15 (E ${ }^{71}$ PGITTNYDT ${ }^{80}$ ) produced the strongest binding with $\mathrm{mAb} A G 3 B$ (Fig. 4a), and there was no significant recognition of a specific Fim2 peptide (Fig. 4b) by this mAb.

\section{Antibody recognition of 'free' linear peptides}

Several peptides, consisting of 19 amino acid residues or greater, were chemically synthesized with their amino acid sequences corresponding to some of the antigenic regions identified from the above epitope mapping procedures (Table 1). Peptide 1Fim2 incorporated the Fim2 antigenic residues recognized by $\mathrm{mAb} 51 / 24$ (Figs. $1 \mathrm{a}$ and $1 \mathrm{c})$; the amino acid sequence of peptide 2 Fim 2 was

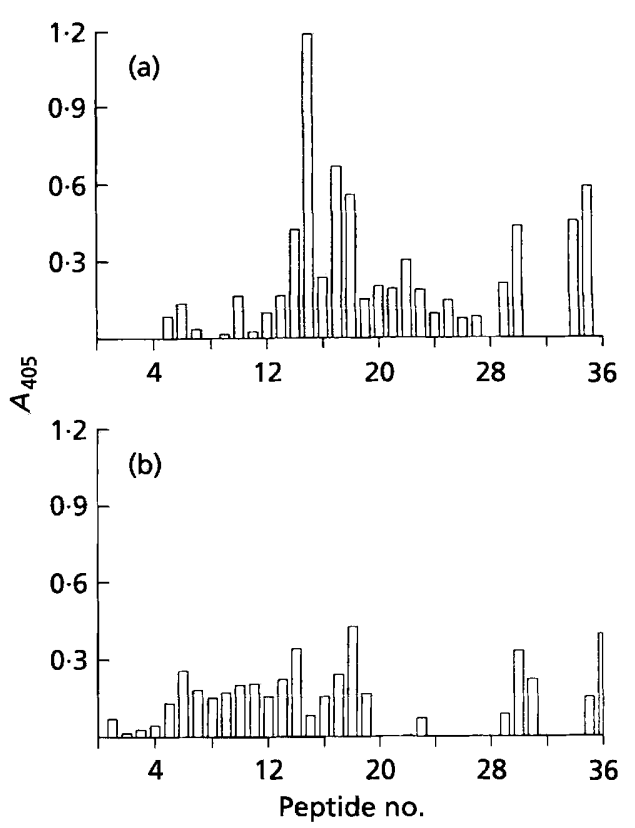

Fig. 4. Epitope mapping with $m A b$ AG3B of 10-residue peptides overlapping by five amino acids which were derived from (a) Fim3 or (b) Fim2.

derived from the C-terminal 20 amino acids of Fim2, which is $66 \%$ homologous with the C-terminus of Fim 3 . The amino acid sequence of 1 Fim 3 spans the antigenic central domain of the Fim3 subunit (e.g. Figs. 3a and 4a), and peptide 2 Fim 3 represents the Fim 3 antigenic peptides 29-31 (Figs. 3a and 4a). When these peptides were coated onto the solid-phase of ELISA plates for use as antigens and subsequently incubated with various anti-protein antibody preparations (Tables 2 and 3), mAb 51/24 was found to recognize peptide 1 Fim 2 strongly and 2 Fim2 weakly (Table 2). Interestingly, mAb 51/21 was also found to recognize 2 Fim2 (Table 2), although this antibody did not demonstrate any significant binding to the 10-residue peptides previously used for the epitope mapping of Fim2 (data not shown). Both peptides 1Fim2 and 2 Fim 2 were recognized by polyclonal anti-native Fim2 sera in this ELISA configuration (Table 2). Of the two peptides derived from Fim3, only the shotter peptide, 2 Fim3, was recognized by $m A$ bs $A G 3 A$ and $A G 3 C$

Table 1. Free peptides

\begin{tabular}{|c|c|c|}
\hline Peptide & Subunit & Amino acid sequence \\
\hline 1 Fim $2 *$ & Fim2 & $G^{82}$ DLRAYKMVYATNPQTQLSN ${ }^{101}$ \\
\hline 2Fim2* & Fim2 & $\mathrm{K}^{161} \mathrm{NGDVEASAITTYVGFSVVYP}^{181}$ \\
\hline 1Fim $3 \dagger$ & Fim3 & $\mathrm{Q}^{61}$ ALGALKLYFEPGITTNYDTGDLIAYKQTYNASGN ${ }^{95}$ \\
\hline 2 Fim $3^{*}$ & Fim3 & $\mathrm{K}^{140} \mathrm{VTNGSKSYTLRYLASYVK}^{158}$ \\
\hline
\end{tabular}

* $\mathrm{GC}$ sequence was added at the $\mathrm{C}$-terminus for protein cross-linking.

tC added to the $\mathrm{N}$-terminus for protein cross-linking. 
Table 2. Antibody ELISA titres obtained with peptide, fimbriae and whole-cell antigens for anti-Fim 2 and antiFim 2 peptide antibody preparations

\begin{tabular}{|c|c|c|c|c|}
\hline \multirow{2}{*}{$\begin{array}{l}\text { Antibody } \\
\text { preparation }\end{array}$} & \multicolumn{4}{|c|}{ Solid-phase antigen } \\
\hline & 1Fim2 & 2Fim2 & $\mathrm{Fim} 2+3$ & $\begin{array}{l}\text { B. pertussis } \\
\text { cells }\end{array}$ \\
\hline $51 / 21 *$ & $<20$ & 70 & 213000 & 31000 \\
\hline $51 / 24^{*}$ & 59500 & 900 & 102400 & 110800 \\
\hline $\mathrm{AG} 2 \mathrm{~A}^{*}$ & $<20$ & $<20$ & 192000 & 54200 \\
\hline AG2B* & $<20$ & $<20$ & 122000 & 30800 \\
\hline Anti-Fim2† & 600 & 60 & 78000 & 67800 \\
\hline Anti-1Fim2/KLH† & 13200 & ND & 50 & $<20$ \\
\hline Anti-2Fim2/cBSAt & ND & 10000 & 600 & 100 \\
\hline
\end{tabular}

ND, Not determined.

* $\mathrm{mAb}$ ascites fluids.

† Murine polyclonal antisera.

Table 3. Antibody ELISA titres obtained with peptide, fimbriae and whole-cell antigen for anti-Fim 3 and antiFim 3 peptide antibody preparations

\begin{tabular}{|c|c|c|c|c|}
\hline \multirow{2}{*}{$\begin{array}{l}\text { Antibody } \\
\text { preparation }\end{array}$} & \multicolumn{4}{|c|}{ Solid-phase antigen } \\
\hline & 1Fim3 & 2Fim3 & $\mathrm{Fim} 2+3$ & $\begin{array}{l}\text { B. pertussis } \\
\text { cells }\end{array}$ \\
\hline AG3A* & $<20$ & 50 & 87300 & 6400 \\
\hline AG3B* & $<20$ & $<20$ & 53600 & 49400 \\
\hline AG3C* & $<20$ & 1600 & 79850 & 13900 \\
\hline Anti-Fim3t & 90 & 100 & 66000 & 28000 \\
\hline Anti-1Fim3† & 29700 & ND & 90 & 30 \\
\hline Anti-2Fim3/BSA $t$ & ND & 4200 & 70 & 20 \\
\hline \multicolumn{5}{|l|}{ ND, Not determined. } \\
\hline \multicolumn{5}{|l|}{${ }^{*} \mathrm{mAb}$ ascites fluid. } \\
\hline Turine polyclonal & tisera. & & & \\
\hline
\end{tabular}

(Table 3). Anti-native Fim3 sera recognized both of the Fim 3 peptides (Table 3 ). It is interesting that two $\mathrm{mAbs,}$ $51 / 21$ and $A G 3 C$, were found to be able to recognize linear peptides in the solid-phase ELISA but not the peptides used in the epitope mapping procedure above. This discrepancy is most likely due to the longer length of peptides 2 Fim 2 and 2 Fim 3 , compared to the 10-residue peptides employed in the pin-peptide mapping.

\section{Anti-peptide antibodies}

To assess whether the peptides listed in Table 1 can induce anti-peptide antibodies which can also recognize the native fimbrial protein, different peptide-carrier protein conjugates were prepared for immunization. The strongest anti-peptide antibody responses were obtained with the following peptide immunogens: 1Fim2 con-

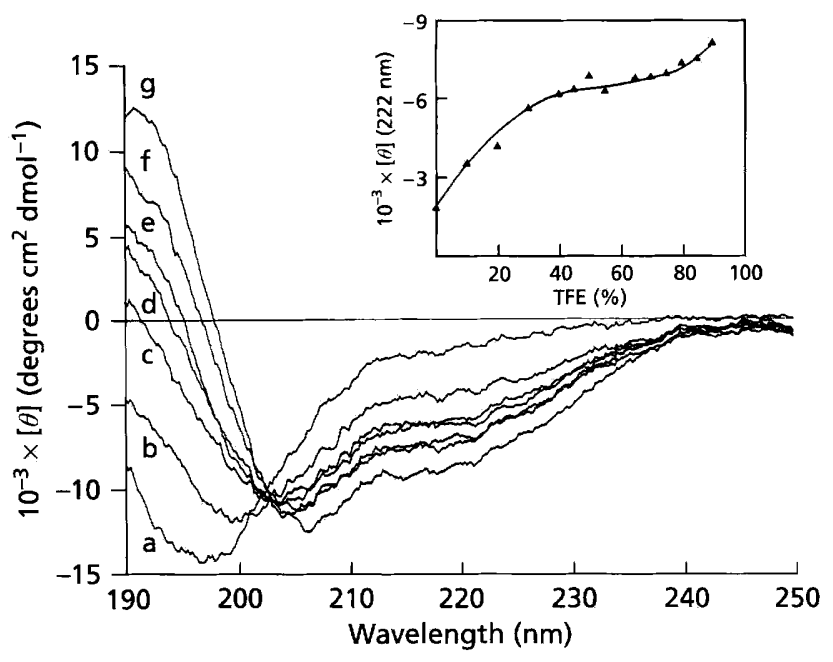

Fig. 5. Far-UV circular dichroism spectra of peptide 1 Fim2 as a function of TFE concentration: (a) $0 \%$, (b) $20 \%$, (c) $30 \%$, (d) $40 \%$, (e) $50 \%$, (f) $70 \%$ and (g) $90 \%$ (v/v) TFE. The inset shows the effect of increasing concentrations of TFE on the mean residue ellipticity of peptide 1 Fim 2 measured at $222 \mathrm{~nm}$.

jugated to KLH via the peptide C-terminal cysteine using MBS as the cross-linker; 2Fim2 conjugated to cBSA, using SMCC; 1Fim3 employed as a free peptide immunogen; and 2 Fim 3 conjugated to BSA using glutaraldehyde. Each of these immunogens induced an antipeptide antibody response (Tables 2 and 3) which recognized the homologous peptide as antigen. Furthermore, each of these anti-peptide antibodies were able weakly to recognize, in an ELISA, a mixed co-purified preparation of native Fim $2+3$ (Table 2 and 3). However, only anti-peptide antibodies induced by 2 Fim 2,1 Fim 3 and 2 Fim 3 were able to weakly recognize whole-cell ELISA fimbriae presented on the surface of $B$. pertussis (Tables 2 and 3).

\section{Peptide structure}

Peptide 1Fim2, which was strongly recognized by mAb $51 / 24$, was investigated by circular dichroism to deduce its propensity to fold into a secondary structure. In the far-UV, the circular dichroism spectrum of the peptide in aqueous buffer, with a negative maximum at about $197 \mathrm{~nm}$ (Fig. 5), was characteristic of a conformation in which no regular secondary structure predominates. However, as the dielectric constant of the solvent was decreased by successive additions of TFE, changes were observed in the circular dichroism spectrum of the peptide (Fig. 5) which were consistent with the formation of $\alpha$-helical secondary structure. The increase in mean residue ellipticity at $222 \mathrm{~nm}$ induced by TFE was used to construct a titration curve which appeared triphasic (Fig. 5). Triphasic TFE titration curves have previously been obtained for a 20 -residue peptide representing the immunodominant domain of the foot-andmouth disease protein VP1 and were interpreted in terms of the ability of the peptide to adopt three different 
conformational states (Siligardi et al., 1991). Thus, although peptide 1 Fim 2 does not appear to possess a regular secondary structure in aqueous buffer, ordered conformations may still be adopted by segments of the peptide sequence in an appropriate environment, which could include the antibody paratope (Stanfield $e t$ al., 1990; Scherf et al., 1992).

\section{DISCUSSION}

The anti-protein $\mathrm{mAbs}$ used in this study do not recognize either SDS- or guanidinium-hydrochloride-denatured fimbriae (Pearce et al., 1992), indicating that the epitopes of the major subunits are either non-contiguous or conformationally dependent. The presence of non-contiguous fimbrial epitopes was confirmed by peptide mapping using $\mathrm{mAb} 51 / 24$, directed against Fim2, and $m A$ bs $A G 3 A$ and $A G 3 B$, which are both directed against Fim3. Specifically, mAb 51/24 strongly recognized free peptide 1 Fim 2 but also weakly recognized free peptide 2 Fim2, whose amino acid sequence is located 60 residues distal to 1 Fim 2 in the amino acid sequence of the subunit. The epitopic mapping profiles derived for antibodies AG3A and AG3B identified the location of epitopic regions throughout the central and $\mathrm{C}$-terminal domains of the Fim3 subunit. An earlier study of ours (Pearce $e t$ al., 1992) suggested that $\mathrm{mAbs} 51 / 24, \mathrm{AG} 3 \mathrm{~A}$ and $\mathrm{AG} 3 \mathrm{~B}$ do not bind to epitopes dependent on quaternary structure. Thus, it is likely that these non-contiguous epitopes are dependent on tertiary structure and are formed by the juxtaposition of the subunit C-terminal and central domains.

The serospecificity of the two fimbrial antigens was shown by the inability of $\mathrm{mAbs} 51 / 24$ and AG3B, directed against Fim2 and Fim3, respectively, to show significant recognition of peptides derived from the heterologous subunit. In contrast, $\mathrm{mAb} A G 3 \mathrm{~A}$, which has been shown to be specific for Fim 3 by different laboratories (Ashworth et al., 1985; Frederiksen et al., 1987), possessed strong binding to the C-terminal 10-residue peptide of Fim2 (peptide 36). The last 9 residues of this peptide are identical to the corresponding Fim 3 amino acids (Mooi $e t$ al., 1990). This cross-reaction at the peptide level suggests that the serospecificity at the protein level may be due to a structural constraint.

The basis for $\mathrm{mAb} 51 / 24$ serospecificity for Fim2, displayed at the peptide level, was investigated by replacement-set analysis of Fim2 peptide 19 (Y ${ }^{91}$ ATNPQTQLS $\left.^{\mathbf{1 0 0}}\right)$. Replacement of those residues in peptide 19 which shared sequence homology with Fim3 peptide 18 did not significantly affect antibody binding, indicating that these amino acids have no direct role in paratope interaction. A similar finding was also obtained for amino acids $\mathrm{A}^{92}, \mathrm{~T}^{93}$ and $\mathrm{T}^{97}$ of the Fim 2 peptide which are not present in Fim 3 peptide 18. In contrast, the sequence $\mathrm{N}^{94} \mathrm{PQ}^{96}$ was crucial for $51 / 24$ recognition, and a single substitution of any of these residues with the corresponding residue of Fim 3 (i.e. $\mathrm{N}^{94} \rightarrow \mathrm{S}, \mathrm{P}^{95} \rightarrow \mathrm{Q}$ or $\mathrm{Q}^{96} \rightarrow \mathrm{N}$ ) resulted in a loss of antibody binding. This is an interesting result, since shortening the $Q^{96}$ side-chain by a single carbon atom was sufficient to disrupt paratope recognition of the peptide. Alternative amino acid substitutions at the $\mathrm{N}^{94}$ and $\mathrm{Q}^{96}$ positions were found to be tolerable for antibody binding. At position $94, \mathrm{Q}, \mathrm{F}$ and $\mathrm{Y}$ could each replace $\mathrm{N}$ without a significant decrease in antibody binding. In the case of the two hydrophobic side-chains, this may be permissible because of their potential for both hydrogen bonding and hydrophobic contacts with aromatic residues. The latter often predominate in antigen-combining sites (Stanfield et al., 1990; Scherf et al., 1992). The $Q^{96}$ replacement with $M$ is difficult to explain without structural information. However, since $\mathrm{N}$ was ineffective at this position, it suggests that $M$ may be making fortuitous contacts with the paratope which are different to those made by the wildtype Q. Proline at position 95 was found to be essential for paratope interaction, a result which has been found for many protein epitopes (e.g. Stanfield et al., 1990; Scherf et al., 1992).

When peptides representing various antigenic domains of the two fimbriae (Table 1) were used as carrier-protein conjugates to immunize, 2 Fim2 induced a strong antipeptide antibody response, whereas the anti-peptide responses induced by 1 Fim 2 and 2 Fim 3 were weaker. 'Free' peptide 1 Fim 3 was found to be immunogenic and it is likely that the T-helper cell epitope(s) contained within the peptide may include amino acids $G^{64} A L K^{67}$, which represent a pattern of amino acids that has been found within many T-helper cell epitopes (Lamb et al., 1987). Each of the anti-peptide antibody preparations were able to recognize Fim $2+3$ coated onto ELISA plates, and, with the exception of serum raised to 1Fim2$\mathrm{KLH}$, were able weakly to recognize native Fim $2+3$ in a whole-cell ELISA. It is particularly interesting that peptide 1 Fim2, prepared as either a peptide-KLH or as peptide-cBSA, -BSA or -thyroglobulin conjugates (coupled using MBS, SMCC, glutaraldehyde and 1-ethyl-3(3dimethyl-aminopropyl)carbodiimide, respectively) was poor at inducing antibodies capable of recognizing native fimbriae (data not shown), since this free peptide, when used as an antigen, was strongly recognized by the antiFim $2 \mathrm{mAb} 51 / 24$. Peptide recognition by the $\mathrm{mAb}$ cannot be attributed to this antibody being induced to a denatured form of the protein (Pearce et al., 1992), as has been indicated for other peptide-reactive anti-protein antibodies (Jemmerson \& Blankenfeld, 1989), since this $\mathrm{mAb}$ strongly agglutinates $B$. pertussis cells. This finding with peptide 1 Fim 2 clearly shows that a peptide which serves as a good mimic of a native protein epitope will not necessarily induce a protein-recognizing response when prepared as an immunogen.

Peptide 1Fim2 was investigated by circular dichroism and was found not to possess an ordered conformation in aqueous solution. However, the TFE titration curve that was obtained for 1 Fim 2 indicated that when exposed to a suitable environment, segments of the peptide can adopt a secondary structure conformation (Siligardi et al., 1991). In the case of 1 Fim2, such an environment may be the $51 / 24$ paratope, which could induce the peptide into a conformation that allows it to mimic the corresponding 
region of the native protein epitope. However, because this conformation is not assumed by the peptide crosslinked to a carrier protein, the anti-peptide antibodies generated fail to recognize the peptide sequence in the fimbriae. Paratope-induced conformational changes in peptide antigens have previously been proposed (Crumpton, 1986) and recently demonstrated by both NMR (Scherf et al., 1992) and crystallographic studies (Stanfield et al., 1990).

In this study we have shown that peptides can be used to locate parts of non-contiguous fimbrial epitopes, but, when these antigenic peptides are prepared as immunogens, the resultant antibodies do not recognize the native protein antigen with high affinity. We have also shown that anti-protein antibodies which do not recognize denatured forms of the fimbriae can bind to peptide fragments of the protein subunits. This may be explained by a requirement for the epitope to be in the correct local conformation, which is lost in the subunit under denaturing conditions, but can be induced in a peptide fragment by the anti-protein antibody paratope.

\section{ACKNOWLEDGEMENTS}

This work was partly supported by grant SP8927650 from the Medical Research Council. We are grateful to Mr R. Wait for mass spectrum analysis.

\section{REFERENCES}

Ashworth, L. A. E., Dowsett, A. B., Irons, L. I. \& Robinson, A. (1985). The location of surface antigens of Bordetella pertussis by immuno-electron microscopy. Dev Biol Stand 61, 143-151.

Cassels, F. J., Deal, C. D., Reid, R. H., Jarboe, D. L., Neuss, J. L., Carter, J. M. \& Boedeher, E. C. (1992). Analysis of Eschericbia coli colonisation factor antigen I linear B-cell epitopes, as determined by primate responses, following protein sequence verification. Infect Immun 60, 2174-2181.

Crumpton, M. J. (1986). The importance of conformation and of equilibria in the interaction of globular proteins and their fragments with antibodies. In Synthetic Peptides as Antigens (Ciba Foundation Symposia, 19), pp. 93-106. Edited by R. Porter \& J. Whelan. Chichester: Wiley.

Frederiksen, J. H., Froholm, L. O. \& Kjennerud, U. (1987). The specificity of antisera against Bordetella pertussi examined by bacterial agglutination. Acta Patbol Microbiol Immunol Scand B95, 363-369.

Getzoff, E. D., Geysen, H. M., Roddas, S. J., Alexander, H., Tainer, J. A. \& Lerner, R. A. (1987). Mechanisms of antibody binding to a protein. Science 235, 1191-1196.

Geysen, H. M., Meloen, R. H. \& Barteling, S. J. (1984). Use of peptide synthesis to probe viral antigens for epitopes to the resolution of a single amino acid. Proc Natl Acad Sci US A 81, 3998-4002.

Green, N., Alexander, H., Olson, A., Alexander, S., Shinnick, T. M., Sutcliffe, J. G. \& Lerner, R. A. (1982). Immunogenic structure of the influenza virus haemagglutinin. Cell 28, 477-487.

Irons, L. I., Ashworth, L. A. E. \& Robinson, A. (1985). Release and purification of fimbriae from Bordetella pertussis. Dev Biol Stand 61 , 153-163.
Jemmerson, R. \& Blankenfeld, R. (1989). Affinity considerations in the design of synthetic vaccines intended to elicit antibodies. Mol Immunol 26, 301-307.

Kent, S. B. H. (1988). Chemical synthesis of peptides and proteins. Annu Rev Biochem 57, 957-989.

Lamb, J. R., Ivanji, J., Rees, A. D. M., Rothbard, J. B., Howland, K., Young, R. \& Young, D. B. (1987). Mapping of T cell epitopes using recombinant antigens and synthetic peptides. EMBO $J \mathbf{6}$, 1245-1249.

Livey, I., Duggleby, C. J. \& Robinson, A. (1987). Cloning and nucleotide sequence analysis of the serotype 2 fimbrial subunit gene of Bordetella pertussis. Mol Microbiol 1, 203-209.

Mooi, F. R., ter Avest, A. \& van der Heide, H. G. J. (1990). Structure of the Bordetella pertussis gene coding for the serotype 3 fimbrial subunit. FEMS Microbiol Lett 66, 327-332.

Pearce, A. M., Irons, L. I., Robinson, A. \& Seabrook, R. N. (1992). Effects of guanidinium hydrochloride on the structure and immunological properties of Bordetella pertussis fimbriae. Biocbem $J$ 283, 823-828.

Preston, N. W. (1985). Essential immunogens in human pertussis: the role of fimbriae. Dev Biol Stand 61, 137-141.

Robinson, A., Gorringe, A. R., Funnell, S. G. P. \& Fernandez, M. (1989). Serospecific protection of mice against intranasal infection with Bordetella pertussis. V'accine 7, 321-324.

Robinson, A., Irons, L. I., Seabrook, R. N., Pearce, A., Matheson, M. \& Funnell, S. G. P. (1991). Structure-function studies of Bordetella pertussis fimbriae. In Proceedings of the Sixth International Symposium on Pertussis, pp. 126-135. Edited by C. R. Manclark and others. DHHS No. 90-1164. Bethesda: FDA.

Scherf, T., Hiller, R., Naider, F., Levitt, M. \& Anglister, J. (1992). Induced peptide conformations in different antibody complexes: molecular modelling of the three dimensional structure of peptideantibody complexes using NMR-derived distance restraints. Biochemistry 31, 6884-6897.

Seabrook, R. N., Robinson, A., Sharma, R. P., Irons, L. I., Ashworth, L. A. E., Price, C. P. \& Atkinson, T. (1990). Recognition of pertussis toxin by antibodies to synthetic peptides. Mol Immunol 27, $777-785$.

Siligardi, G., Drake, A. F., Mascagni, P., Rowlands, D., Brown, F. \& Gibbons, W. A. (1991). Correlations between the conformations elucidated by CD spectroscopy and the antigenic properties of four peptides of the foot-and-mouth disease virus. Eur J Biochem 199, 545-551.

Stanfield, R. L., Fieser, T., Lerner, R. A. \& Wilson, I. A. (1990). Crystal structures of an antibody to a peptide and its complex with peptide antigen at $2 \cdot 8 \AA$. Science $248,712-719$.

Steven, A. C., Bisher, M. E., Trus, B. L., Thomas, D., Zhang, J. M. \& Cowell, J. L. (1986). Helical structure of Bordetella pertussis fimbriae. J Bacteriol 167, 968-974.

Tallet, A., Seabrook, R. N., Irons, L. I., Robinson, A., van Heyningen, S. \& Atkinson, T. (1993). Localisation of a receptor domain on the $\mathrm{S} 3$ subunit of pertussis toxin by peptide mapping. Eur J Biochem 211, 743-748.

Willems, R. J., van der Heide, H. G. J. \& Mooi, F. R. (1992). Characterisation of a Bordetella pertussis fimbrial gene cluster which is located directly downstream of the filamentous haemagglutinin gene. Mol Microbiol 6, 2661-2671.

Received 16 June 1993; revised 6 August 1993; accepted 10 August 1993. 